\title{
Tanni Grey-Thompson - 'The one that got away': A theological analysis of foeticide, infanticide and the deviant Paralympic success story
}

Sport in Society

Braye, Stuart

Department of Psychology, Sport \& Exercise, School of Social Sciences, Business and Law, Teesside University, Middlesbrough, UK

Email: s.braye@tees.ac.uk a

\begin{abstract}
In this essay, I apply a theological perspective to argue that the Paralympic Games, its athletes, and the media, unwittingly collude to demonstrate contempt towards the killing of disabled children, whilst claiming that disability equality has been improved or achieved. I argue that British Paralympic athlete Tanni Grey-Thompson was destined to succeed because many of her potential competitors were denied the right to life. British newspapers and publicly available figures related to the killing of disabled children in the United Kingdom are contrasted against the positive narrative about disabled people promoted by the International Paralympic Committee. I make reference to Christian bio-medical ethics to draw attention to the medical profession's negative attitudes towards disabled people in the early 1900s, which provided execution techniques for the Nazi holocaust. I conclude by contending that the genocide of disabled children continues unabated despite the positive and dominant discourse attached to the Paralympic Games.
\end{abstract}

\section{Introduction}

Within disability studies Christianity is largely ignored or placed in a historical context thus ignoring a theological perspective on the lives of disabled people (see Barnes and Mercer 
2011). Similarly, disability sport discourse excludes a theological perspective of disabled people in sport and often dismisses Christianity or contextualizes it historically (see Thomas 2003). The lack of a theological perspective on the elite Paralympic Games and grass roots disability sport is considered an oversight by Watson and Parker (2015). Furthermore, a theology of disability and disability sport are legitimate areas of discourse and contribute much to the broader understanding of disability issues (cf. Braye 2014; Brock and Swinton 2012; Eiesland 1994; Hauerwas 1986, 2004a; Watson and Parker 2015).

Paralympic sport is transitory for the athletes, yet being a disabled person is permanent and the circumstances of disability continue for Paralympians beyond sports competition. It would seem logical, therefore, to use the Paralympic Games to raise disability issues beyond the confines of sport due to the International Paralympic Committee's (IPC) claim that the Games has a positive impact on all disabled people (IPC 2015). The connection between the worldwide foeticide and infanticide of disabled children ought to be directly linked to the global Paralympic Games as it is the antithesis of the equality that the IPC claim is evolving. The United Kingdom's (UK) Government Department for Culture, Media and Sport (DCMS) also support the notion that the London 2012 Paralympic Games had a positive impact, stating:

The [London 2012 Paralympic] Games improved attitudes to disability and provided new opportunities for disabled people to participate in society. (DCMS 2013, 3)

This type of statement formed a powerful and positive narrative around the London 2012 Paralympic Games that was largely supported by the media and some disabled people. British newspapers The Guardian, The Independent, The Telegraph and The Times, all featured articles that were either about successful Paralympians or other disabled people who promoted a positive message. For instance, on 9 September 2012, former Royal Marine, Arthur Williams, 
a television presenter and Paralympic cyclist, wrote the following on The Guardian's official website:

In just one and a half weeks, there has been such a profound change in how people perceive disability and that has taken people by surprise. It has shocked a lot of people. As a country, we were really open-minded going into the Games and it has lived up to expectations. No one has been disappointed. (Williams 2012)

Disabled commentators like Williams were triumphant because they appeared to suggest that a victory had been achieved in the quest for disability equality. It becomes difficult, and arguably unpopular, to point out that the 'jubilant games' portrayal of the Paralympics is not all it seems (Braye, Dixon and Gibbons 2015, 18). However, the evidence ought not to be ignored just because it contradicts the positive Paralympic discourse. My intention is to analyse this contradictory reality as it balances the positive images and stories that emanate from the Paralympic Games. One such contradiction is the rise in hate crimes against disabled people in England and Wales since the London 2012 Paralympics. Statistics reported by the Crown Prosecution Service indicate the following:

The number of prosecutions for hate crimes against disabled people has surged by 41.3 per cent from 2015-16. In that same period there were 941 prosecutions for disability hate crimes, official figures show. (CPS cited in The Telegraph July 13, 2016) 
These figures stand in contrast to the claims of the IPC, the DCMS and the positive media portrayal of the Paralympic Games.

Drawing upon previous theological discourse on Christian bio-medical ethics, in this paper I argue that rather than being a successful athlete among equals in an era of increasing equality for disabled people, Tanni Grey-Thompson was destined to succeed because her potential rivals were denied the right to life. I will use the term 'impairment' as a description of the shape or function of a person's body, and the term 'disability' to describe the way an individual or society discriminates against a person because of their impairment. This is in line with the social model construction of disability discussed predominantly by UK based disability activists over many years (cf. Barnes and Mercer 2011; Barnes 1991; Campbell and Oliver 1996; French 1994; Goodley 2004; Oliver 1990, 1996; Shakespeare and Watson 1997).

In Shakespeare's $(2017,197)$ helpful overview of the social and medical models of disability, he describes impairment as 'individual and private' and disability as 'structural and public'. Treating people as medical conditions and the dominance of the medical profession over the lives of disabled people was resisted as the 'medical model of disability' by the authors previously listed. They adhere largely to an alternative 'social model of disability' that presses society to make changes to accommodate disabled people in spite of their impairments. Within the theology of disability, analyses of these models have been applied and discussed to some extent with contributions related to specific impairment groups (Block 2002; Gillibrand 2010; Ray 2006). Eiesland (1994) considers the social construction of disability more critically, however, the most rigorous analysis is by Morris (2008) albeit specifically related to Deaf people.

In the Paralympic Games a contentious medical classification system is applied to athletes for competition (Howe 2008, 2011; Howe and Jones 2006; Peers 2009, 2012). Athletes in some sports, such as wheelchair racing, are placed into competitive groups based on having 
similar functional ability, rather than being placed into impairment specific groups, such as goalball for people with a visual impairment. As such Grey-Thompson would have been competing in wheelchair racing against athletes with a range of impairments. As we see in the Olympics, a greater number of competitors leads to more fierce competition, and this is commonly recognized as coming from the traditional 'sports development continuum' (Hylton $2013,5)$. In this traditional model, the structure of sports engagement is illustrated as a pyramid with a broad base of foundation at the bottom ascending to participation, performance and finally excellence at the peak. This is not the case for disabled people in sport and this pyramid has been reconstructed as follows:

The structure of sport for disabled people is a precariously balanced upside-down pyramid with excellence at the top in the format of the Paralympics and increasingly in the CG [Commonwealth Games], with limited opportunities below. The pathways are unclear, and where they do exist they are not for all disabled people, and not in all sports. Paralympic participation itself is limited only to those disabled people for whom classification by impairment or function is achievable. (Braye, Gibbons and Dixon 2017, 132-133)

My argument is that if there had been less abortions of disabled children then there may well have been a greater source of disabled people from which to draw competitive athletes. Because Grey-Thompson was born with Spina bifida, I use this as a specific example of impairment in relation to foeticide and infanticide. It is one of a number of impairments detectable by antenatal screening, others including: Down's syndrome, hydrocephalus, anencephaly, Huntingdon's disease and Duchenne muscular dystrophy (Sharp and Earle 2002). The media discussions about Spina bifida are relevant to my argument as they appear in the same era as 
Grey-Thompson's birth. Though I may be appearing to contradict my adherence to the social model by introducing specific impairments here; foeticide and infanticide are often justified by impairment.

My position on when life begins is theological, and as such I believe that a child's life begins at conception and is alive in utero. My position is based on the following Biblical references:

For you created my inmost being; you knit me together in my mother's womb.....My frame was not hidden from you when I was made in the secret place. When I was woven together in the depths of the earth, your eyes saw my unformed body. All the days ordained for me were written in your book before one of them came to be. (Psalm 139:13, 15, 16) ${ }^{1}$

In Luke's gospel when the angel Gabriel appeared to Mary, Jesus' mother, he told her of her relative Elizabeth's pregnancy with John the Baptist:

Even Elizabeth your relative is going to have a child in her old age, and she who was said to be barren is in her sixth month (Luke 1:36).

In the verses that follow Gabriel's visit to Mary we see that 'When Elizabeth heard Mary's greeting, the baby leaped in her womb' (Luke 1:41). Elizabeth makes several statements after being filled with the Holy Spirit and says, “"As soon as the sound of your greeting reached my ears, the baby in my womb leaped for joy"' (Luke 1:44). The often quoted Christmas passage from Isaiah 6:9 'For to us a child is born, to us a son is given...' can lead us to overlook the fact that Jesus did not suddenly appear as the prophesied child on earth. He did 
indeed come to earth, specifically to Mary's womb at conception by God the Holy Spirit for a nine month period. Life for the human Jesus of Nazareth began in utero, and if life is so important to God that it began for Jesus at conception, it would seem logical, from a theological viewpoint at least, to agree.

When Carys Davina Grey was born on 26 July 1969, her parents, like many others, could not have imagined what the future would hold for their daughter. She is now Baroness Tanni Grey-Thompson, a Crossbench Peer in the UK's House of Lords, a former Paralympic athlete and one of the UK's most recognised disabled people. A distinguished 16 year sporting career over five Paralympic Games, brought her 16 Paralympic medals including 11 gold, four silver and one bronze. In this capacity, she is able to use her experiences to influence a range of issues related to disability equality in the UK. Grey-Thompson is living what would be considered by any standards an interesting and productive life. In the 1960s and 1970s, however, other children with the same impairment as Grey-Thompson - Spina bifida - were denied the right to life by being aborted, or left to die (Eckstein, Hatcher and Slater 1973; Roberts cited in The Times 1972, 2; The Times 1982, 11).

\section{Medals and murder}

In 1969, the first full year after the 1967 Abortion Act was passed, 49,829 abortions were carried out on women living in England and Wales. In 1972 this figure had risen to 108,565 (RCOG 2008). It is clear that the medical profession has worked in some tension over the issue of abortion since it became a legal practice, and the treatment of disabled babies in particular. Four years after the birth of Grey-Thompson an article in The Times newspaper, UK, reported on the attitude of some medical doctors towards disabled children. This had been published as a discussion in the British Medical Journal (BMJ): 
Dr Hatcher agrees with Mr Herbert Eckstein, a consultant paediatric surgeon, and Dr Eliot Slater a psychiatrist, that "the best for an individual baby and his family may be to let him die within a month". He suggests that the question "What right have I to recommend withholding treatment?" should be offset against another: "What right do I have to inflict major chronic suffering on another human being and his family?" (Eckstein, Hatcher and Slater 1973; The Times 1973, 3)

There is an assumption among these three doctors, at least, that medical knowledge automatically leads to the right ethical decisions. The infanticide they are discussing, bearing in mind that some of those left to die actually survive, is not something for which official figures are kept. The idea that women and their families are 'horribly oppressed by disabled children' is beyond the remit of sound medical advice (Saxton 2017, 81). In medical practice, early technological advances meant that doctors were able to monitor unborn babies more closely. Part of these advances led to the detection of some specific impairments in the unborn child, including Spina bifida. Advances in medical technology for some have led to disadvantages - foeticide - for others. The tension over the decisions whether to treat or not to treat, disabled children immediately after birth has been somewhat of an ethical dilemma for doctors. The same article in The Times continues in relation to Spina bifida directly, and in the time covering Grey-Thompson's birth in 1969:

Mr Eckstein said that between 1963 and 1970, most such infants were energetically treated. As the patients became older, it became clear that the handicaps were often severe and that facilities for their care and their education were totally lacking. "For these reasons, some selection for treatment is now widely practised." 'Each baby should be assessed individually and the decision to treat - "or especially not to treat" 
must be taken at consultant level, he said. Dr Slater said: "There has to be an order of priorities: keeping some patients alive means letting others die. We must face as inescapable the duty to let some patients die." But the financial costs of the preservation of life at all costs were often less than the suffering involved. A child could become "a parasite on the family and destroy it". The strength of the mother went into supporting the child and this could "completely distort and pervert family life". He believed it was never of benefit to a mother to be saddled with an abnormal baby. (The Times 1973, 3)

This approach, suggests that Grey-Thompson is fortunate to be the one that got away, as it seems that being born with Spina bifida in 1969 was a risky start to life. However, it is evident in the full original article in the $B M J$ that many medical professionals at this time were against withholding treatment from disabled children, no matter how severe their impairment:

The point that has alarmed me recently is that an increasing number of fetuses with spina bifida or hydrocephalus are now recognized before birth, by x-ray. Many of these babies are delivered by caesarean section and I have tried to persuade obstetricians not to resuscitate them if they're severely deformed - but many have objected violently. (Eckstein Hatcher and Slater 1973, 286)

The differences of opinion in the approaches taken in the 1970s highlighted in these extracts remains today. Despite legislation and the wide acceptance of abortion and its place as a relatively safe medical procedure, it is 'still a distressing experience' for those involved as the RCOG State: 
Safe abortion is easily taken for granted and increasing numbers of trainees want nothing to do with this service. Conscientious objection is the right of every doctor but that decision needs careful consideration. Nobody enjoys performing abortions. The doctors who do so are the ones who feel most strongly about reducing the need for abortion, and many work in difficult circumstances giving contraceptive advice to young women. (RCOG 2008)

The tensions around foeticide and infanticide of disabled children specifically is apparent in the following extract from a controversial article by Giubilini and Minerva (2013):

When circumstances occur after birth such that they would have justified abortion, what we call after-birth abortion should be permissible. In spite of the oxymoron in the expression, we propose to call this practice 'after-birth abortion', rather than 'infanticide' $(2013,261)$.

Giubilini and Minerva's perspective has been robustly challenged on ethical grounds by several authors (cf. Beard and Lynch 2013; Beckwith 2013; Manninen 2013; Laing 2013). However, the fact that intellectuals still have such a view places disabled children in a perilous and unique position in comparison to their non-disabled peers. Since the UK Abortion Act of 1967 was passed a total of 8.2 million abortions have been carried out, including over 185,824 in England and Wales in 2015, the year preceding the 2016 Rio Paralympic Games (Dept. of Health 2016; ONS 2008; Saunders 2007). Current statistics show that of these 185,824 abortions, 3,213 specifically related to disabled children under 'ground E' of the 1967 Act, which relates to the risk that the child would be born with an impairment (Dept. of Health 2016, 5). During 2015 Scotland had 12,082 abortions, of which 186 were carried out under 'ground E' (NHS Scotland 
2016). Of the 16 abortions in Northern Ireland in the same time period, it is unclear if any were under 'ground E' (Dept. of Health NI, 2016). If we take the 2015 figures as a guide for 2016, adding England and Wales 3,213 to 186 in Scotland this gives a total 3399 under 'Ground E'. This would mean that during the 12 days of the Rio 2016 Paralympic Games, nine disabled children were aborted each day in Great Britain; whilst the Great Britain team won just over 12 medals each day. This reality is far removed from the argument that the Paralympic Games is having a positive impact on the everyday lives of disabled people in wider society. Furthermore, this same comparison can be made in the other 169 countries where abortion is permitted, the majority of which 'have some provision for terminating pregnancy on the grounds of severe impairment' (Sharp and Earle 2002, 140).

I suggest that the term fetus in some way dehumanizes the unborn child by softening the reality of killing a living human being. I use the term 'disabled children' rather than 'disabled fetuses' to augment Saxton's view:

When we refer to the fetus as a disabled (rather than a defective) fetus, we personify the fetus via a term of pride in the disability community. $(2017,80)$

Where abortion is concerned debates centre around several ethical arguments such as: fetal and father rights as subordinate to the mother's rights and personal autonomy; disability rights and fears around eugenics; at what stage of pregnancy abortions are carried out; the medical counselling offered to women pregnant with a disabled child; the sanctity of life; and, the fact that abortions on disabled children can be carried out up to full term (Sharp and Earl 2002; Pritchard 2005). The quest for women's rights and personal autonomy has led to the unnecessary deaths of innocent unborn children, probably half of whom were, or are, female. These abortions may have been reasoned as necessary for the mothers, though not necessary 
for the children. The death of the children was to satisfy the necessities of the mothers. This is not to suggest that my position is anti-feminist, rather that I am pro-life. To be pro-life it does not necessarily follow to be anti-feminist, bearing in mind the fact that females are aborted too. My theological point here is to 'speak up for those that cannot speak for themselves' (Proverbs 31:8, 9). The key arguments I listed are not the only considerations of course, but for our purposes we focus on the disabled child. In the same era that these ethical discussions were taking place, the late French biologist, Jean Rostand $(1970,89)$ was also discussing abortion on the grounds of impairment:

I believe that a terrible precedent would be established if we agreed that a life could be allowed to end because it was not worth preserving, since the notion of biological unworthiness, even if carefully circumscribed at first, would soon become broader and less precise. After eliminating what was no longer human, the next step would be to eliminate what was not sufficiently human, and finally nothing would be spared except what fitted a certain ideal concept of humanity.

Whatever the motives of the doctors of the 1950s, 60s and 70s, the issues around the killing of unborn and newly born disabled children remain the same. Change of language, medical techniques, the passing of decades and even notions of advancing civilization should not automatically lead us to think too differently about foeticide and infanticide today. In Germany in the 1930s it was medical professionals who were advancing the execution of the chronically sick and implementing what Rostand became concerned about some 40 years later. Hitler's extermination of those people whose lives were considered 'not worthy to be lived' came after Germany's medical profession had already pedalled the propaganda in the 1930s (HanauskeAbel 1996, 2; Koop 1980, 91). Indeed, abortion in Germany began around 1900, was supported 
by the intellectual elite by 1911 , and followed by 'the euthanasia movement against worthless people' circa 1920 (Koop 1980, 91).

Hanauske-Abel $(1996,1453)$ suggests that in 1933 the direction of the German medical community 'even outpaced the new government'. The organisation responsible for the killing of children who were chronically sick was surreptitiously called 'Realms Committee for Scientific Approach to Severe Illness Due to Heredity and Constitution' (Koop cited in Reagan 1984, 63). In his book on abortion, President Ronald Reagan (1984) included two chapters: one by C. Everett Koop called 'The slide to Auschwitz'; the other by Malcom Muggeridge called 'The Humane Holocaust' (1980). From these two pieces of work, and others, one can conclude that lessons from $20^{\text {th }}$ century attitudes towards disabled people have not been fully learned. For instance, In the 1920s and 30s in Germany, before Hitler was widely known, an acceptance of euthanasia began to emerge. In 1920/2012, two German professors, psychiatrist Alfred Hoche and jurist Karl Binding published a book translated as, Allowing the Destruction of Life Unworthy of Life. They advocated the killing of 'absolutely worthless human beings', their reason was that the money saved by killing one human being led to opportunities for others (cited in Muggeridge 1980, 18-19). Following the Nuremburg War Crimes Tribunal an American Counsel, Dr. Leo Alexander, reflected on how the holocaust had begun:

It started with the acceptance of the attitude, basic in the euthanasia movement, that there is such a thing as life not worthy to be lived. (Muggeridge 1980, 18)

Whether the taking of human life is based on notions around the unworthy life, the quality of life, the cost of life or mercy-killing, the Nazi's murder techniques and processes had their beginnings in hospitals and were carried out by medical professionals. Indeed, 16 of those convicted of war crimes following WWII were doctors and one a nurse, seven of whom received 
the death sentence and were hanged on June 2, 1948. Among them were Dr. Karl Gebhardt, who was awarded a $\mathrm{PhD}$ in medicine from Munich University in 1923, was president of the German Red Cross, and was also a,

distinguished professor of orthopaedics who made an outstanding contribution to the foundation of sports medicine and developed competitive sport for the disabled as a means of therapy...He focused his work on returning the disabled to an active working life. (Silver 2011, 366)

The Nazi driven genocide of the 1933-1945 era began with techniques developed earlier by doctors and nurses. What was seen as an inhumane holocaust then, has been superseded by what Muggeridge first called 'the humane holocaust' when referring to abortion (Muggeridge 1980, 18). He further explained that in 1979, which was called the 'Year of the Child', approximately 50 million abortions were carried out worldwide (Muggeridge 1980, 19). The evidence suggests that when the lines become blurred around quality of life and mercy killing, the most vulnerable in society are most at risk, and none are more at risk than the unborn or defenceless disabled child. I concur with Rostand who, whilst having been an agnostic, had a view with which a Christian theological perspective finds common ground, he stated:

I have the weakness to believe that it is an honor for a society to desire the expensive luxury of sustaining life for its useless, incompetent, and incurably ill members; I would almost measure a society's degree of civilization by the amount of effort and vigilance it imposes on itself out of pure respect for life. It is noble to struggle unrelentingly to save someone's life as if he were dear to us, when objectively he has no value and is not even loved by anyone. (Rostand 1970, 89-90) 
It would appear that as a society we remain far removed from this type of thinking today. Beauchamp and Childress (2001) discussed the biomedical ethical issues around treatment of people who are terminally ill. Their premise around 'considering the patient's quality of life to considering the patient's value for society' has the fear, they suggest, "that the "right to die" will be transformed into the "obligation to die", perhaps against the patient's wishes and interests' (Beauchamp and Childress 2001, 126-7). In the UK we live in a society where it appears that the role of the unborn, or newly born, disabled child is to be obliged to die, because that is what, we, as a society have decided is their role. It is against their wishes and interests, it is murder.

\section{Subconscious resistance}

Paralympic athletes, seemingly unaware of the ethical dilemmas mentioned above, find themselves subconsciously adopting the role of the unwanted disabled child and resisting notions of being insufficiently human. Whilst discussing people who he referred to as 'mentally handicapped', theologian Stanley Hauerwas (2004b, 193) suggested that, 'Their existence does not need to be justified - which is but a reminder that no one's existence needs to be justified'. In this argument that 'no one's existence needs to be justified' there are two points to be considered if we assume that one's existence is in danger of being unjustified. For example, if group 'A' points at group 'B' and proclaims 'your existence is unjustified' a logical response for group 'B' may be to ignore that view because 'no one's existence needs to be justified'. However, if group 'B' points at itself and proclaims 'our existence needs to be justified' we must logically conclude that group ' $\mathrm{B}$ ' has a distorted view of itself based on believing the original claim of group 'A'. Applying this last point to disability and the Paralympics in particular, the IPC president, Sir Philip Craven, made an interesting comment in The Guardian 
online (26 August 2012) prior to the London 2012 Paralympic Games. He stated 'This is sport. It's not disability anything. I come from sport' (Gibson 2012). It would appear that Craven is aware, to some extent at least, of the negative views towards disabled people to the extent that he seeks to remove the term 'disability' from the world's largest disability sport event, in the hope that society will refocus only on Paralympians' athleticism. If I may put this into the imaginary thought process of a Paralympian:

I am a disabled person, therefore, I have no value. But if I prove I have athleticism, I have value. Please ignore my valueless disability by focusing on my valuable athleticism.

This perceived anomaly of Paralympic athletes as disabled people is an inescapable fact that remains uncomfortably attached to the Paralympics. In their own 2015-2018 strategic plan, the IPC make a number of statements as follows:

To make for a more inclusive society for people with an impairment through parasport.

The Paralympic Games are the world's number one sporting event for transforming society's attitudes towards impairment.

Equality - through sport, para-athletes challenge stereotypes and transform attitudes, helping to increase inclusion by breaking down social barriers and discrimination towards people with an impairment. (IPC 2015, 14) 
Athletes from all five continents compete in venues full of spectators and an ever expanding global TV audience. Such worldwide reach, means that the Paralympic Games act as a catalyst for greater social awareness thus contributing to the development of a more equitable society with respect and equal opportunities for all. (IPC 2015, 18)

The IPC, I argue, appears aware of the weakness associated with disability and the fragility of the disabled athlete dichotomy. Because of this they strongly promote the opposite, denying that disability is a necessary term. Indeed, the term 'disability sport' has been replaced with 'para-sport', an abbreviation of 'Paralympic sport'. The term 'disability sport' seems to have been dropped by those associated with the Paralympics. I suggest that this can be seen as a veiled plea not to be killed, and this rhetoric continues in the IPC strategy as they set out their raison d'être:

To enable para-athletes to achieve sporting excellence and inspire and excite the world.

Courage - para-athletes through their performances showcase to the world what can be achieved when testing your body to its absolute limits.

Determination - para-athletes have a unique strength of character that combines mental toughness, physical ability and outstanding agility to produce sporting performances that regularly redefine the boundaries of possibility. 
Inspiration - As role models, para-athletes maximise their abilities, thus empowering and exciting others to participate in sport. (IPC 2015, 14)

The IPC is an organization intrinsically associated with disability and an increasingly high sports profile. This creates a problem for disabled people as the views of the IPC become more widely acceptable in society (Braye 2017). The IPC are arguably resisting a negative stereotype of disability, with an overly positive stereotype. However, sport has a unique way of creating a problem for disabled athletes in particular. Tänssjö $(1998,23)$ posed the question, 'is our admiration for sports heroes fascistoid?' He suggested that the admiration of sports heroes rests on the premise that, the very act of admiring such heroes, means ipso facto that those who fail are held in contempt. In relation to this he further argued that 'the hard core of Nazism was a contempt for weakness' (Tänssjö 1998, 26) and set out three forms of contempt:

First, contempt can take an aggressive form, as was the case with the Nazis. They wanted to exterminate weakness (by exterminating those who were weak). Second, contempt can take a negligent form. We try not to think at all about those for whom we feel contempt. We "think them away". We treat them as nonexistent. We do not care about them at all. Third, contempt can assume a paternalistic form. We want to “take care" of those "poor creatures" for whom we feel contempt. (Tänssjö 1998, 27)

The IPC narrative and those of the athletes who compete in the Paralympic Games fit aptly with the first two forms. Firstly, aggressive contempt; the IPC want to kill off the term disability and deny that it exists, they see it as weak to conform to a disability identity which hinders their progress. The fact that those that take part in the Paralympics as athletes are already identified as heroic suggests to a viewing public that the perceived weakness of disability has 
been exterminated. Secondly, negligent contempt; Paralympic athletes do criticize non-athletic disabled people for whom they have no care. For instance in 2012, the American Paralympic sprinter, Jerome Singleton stated the following in an interview with The Guardian:

We all know somebody with a disability and now we can point to the Games and ask them: "Why aren't you seeking to become a Paralympian?" (Bagchi 2012)

This type of contempt is not criticized by the IPC who appear to support this view in their own strategies. I contend that the IPC is all too aware of the aggressive contempt towards disabled people and they are desperate to distance themselves from it. Furthermore, I suggest, that the aim of the IPC appears to be to distance themselves from other disabled people. They are complying with an implicit obligation that disabled people have to prove that they are valuable to society. In so doing, they actively disassociate themselves from other disabled people, who they see as less valuable. However, to some extent, for a disabled person to have a negative view of another disabled person is to have a negative view of oneself.

If disabled people who cannot become Paralympic athletes are treated with contempt by other disabled people, then a hierarchy of disability is apparent. Campbell and Oliver (1996) correctly suggested that disabled people are not a homogenous group, and the Paralympics highlights the many differences (Braye, Dixon, and Gibbons 2015). Criticism goes various ways, and Deal (2003) recalls the experience of living in a residential home in the 1980s:

Populated primarily by young men with Duchenne muscular dystrophy, 'SuperCrip' was used in a disparaging manner to describe other wheelchair users who took part in marathons, drove cars, etc., using their upper body strength to the full. Hence, these young men with a muscle wasting impairment, ridiculed 
others (through the use of language) and thus distanced themselves from more athletic groups of disabled people. (Deal 2003, 897-8)

Aggressive contempt is, to some extent, the most frightening, and the most vulnerable disabled people are the in utero and new born children. To conclude my overall theological analysis, Jesus clearly addresses his 'aggressive contempt' for people who show 'negligent contempt' for people he sees as vulnerable and in need:

Then he will say to those on his left, 'Depart from me, you who are cursed, into the eternal fire prepared for the devil and his angels. For I was hungry and you gave me nothing to eat. I was thirsty and you gave me nothing to drink, I was a stranger and you did not invite me in, I needed clothes and you did not clothe me, I was sick and in prison and you did not look after me.' They also will answer, 'Lord, when did we see you hungry or thirsty or a stranger or needing clothes or sick or in prison, and did not help you?' He will reply, 'I tell you the truth, whatever you did not do for one of the least of these, you did not do for me'. (Matthew 25:41-45)

Here, Jesus is closely aligning himself with the most helpless of people and placing their value at a high premium. To care for and feed the hungry, water the thirsty, accommodate strangers, clothe the naked, look after the sick and look after those in prison, is a basic principle of Jesus' instructions. To carry out these basic tasks is equivalent to ministering to Jesus himself, he says here, to ignore them is un-Christian, and in his eyes, evil. This theological viewpoint has long been preached, practiced and defended by many Christians since the first century and can be a last line of defense when it comes to making decisions about disabled children. If the fear of 
God prevents the killing of disabled children, then perhaps that is a positive outcome for those children.

\section{Conclusion}

On the evidence I have presented, and that is readily available in the public domain, disabled children who were alive have their lives taken from them on a daily basis. Their lives are ended predominantly on the decisions of medical professionals, and supported by a society that legally permits these acts of contempt for human life.

Of the Ten Commandments in the Bible, the sixth is 'You shall not murder' (Exodus 20:13) and the so-called ethical reasons that medical professionals use as a justification are nowhere found in Scripture. When referring to murder, Jesus pulls the point right back to saying that someone who gets “" ... angry with his own brother will be subject to judgment”" (Matthew 5:22). It appears that medical professionals are able to take the lives of innocent disabled children, without overt anger, based on ethical decisions emanating from their medical opinions. These non-angry acts of contempt for disabled children are very much like what Muggeridge (1980) was referring to when he suggested that abortion was a 'humane holocaust'. Other Biblical commands are clearly evident such as 'speak up for those that cannot speak for themselves' (Proverbs 31:8, 9) and this is the motivation for my argument. These deaths are a human tragedy, it is genocide, and it is a holocaust, humane or otherwise. The fact that millions of children, some of whom were disabled, have been killed, perhaps ought to make us reconsider how humane and civilized we claim to be.

I have focused on the foeticide and infanticide of disabled children in the UK during 2015 specifically. However, these alone whilst numbering approximately 3,399 are a small percentage of the total 197,922 children in the UK denied the right to fight for the lives they had (DoH 2016; DoH NI 2016; NHS Scotland 2016). One of the deviant aspects of the 
Paralympic Games, as I see it, is that whilst it is a spectacular sporting event in its own right, it does give the false impression that equality for disabled people has indeed arrived. It is, perhaps, disappointing that many disabled people, including those involved with the Paralympic Games appear to believe this too. Part of my argument lies in the premise that some of the disabled children whose lives were ended in utero or soon after birth may have become Paralympic athletes. This is of course unknown, but the fact that Grey-Thompson was born with Spina bifida in an era when some medical doctors were ending the lives of other children with the same impairment, is my justification for making the claim. My evidence suggests that we are still in this era of killing children unnecessarily, whilst pretending that we live in a time of advancing equality.

The application of the medical model of disability is arguably at its most dangerous in the hands of the medical profession when tasked with the care of society's most vulnerable people. The Paralympic Games is a sports event for people who acquired an impairment and for the remnant of people who were born with an impairment. I believe that it is right to use the Paralympics to raise important emotive issues such as foeticide and infanticide, particularly since the IPC make bold claims about the Paralympic Games' ability to improve the lives of disabled people beyond sport and in wider society. And finally, it is quite possible that while a gold medal Paralympic athlete is watching their national flag being raised, back home a child with the same impairment is being aborted, perhaps stopping the flag half way would be an appropriate gesture.

\section{Notes}

1. All Bible references in this essay are from the 1989 edition of the New International Version (NIV). 


\section{References}

Bagchi, Rob. 2012. "Paralympics 2012: Jerome Singleton is on a crusade." The Guardian, July 23. Accessed 2 March 2017.

https://www.theguardian.com/sport/2012/jul/23/paralympics-2012-jerome-singletoncrusade

Barnes, Colin. 1991. Disabled People in Britain and Discrimination: A Case for AntiDiscrimination Legislation. London, UK: Hurst \& Company.

Barnes, Colin, and Geof Mercer. 2011. Exploring Disability, a Sociological Introduction. Cambridge, UK: Polity Press.

Beard, Matthew, and Sandra Lynch. 2013. "Personhood, Harm and Interest: A Reply to Alberto Giubilini and Francesca Minerva.” Journal of Medical Ethics (39): e1-e4. doi.org/10.1136/medethics-2012-100692.

Beckwith, F. J. 2013. "Potential and Burdens: A Reply to Giubilini and Minerva." Journal of Medical Ethics (39): 341-344. doi.org/10.1136/medethics-2012-100844.

Beauchamp, T.L. and J.F. Childress. 2001. Principles of Biomedical Ethics. $5^{\text {th }}$ ed. New York: Oxford University Press. 
Block, Jennie, W. 2002. Copious Hosting: A Theology of Access for People with Disabilities, Publisher: Continnuum-3PL.

Braye, Stuart. 2014. “"Meet My Exes: Theological Reflections on Disability and Paralympic Sport - a Continuum of Ephemeral Deaths and Eternal Resurrection.” Sports, Religion and Disability (Special Edition). Journal of Disability \& Religion 18 (2): 127-141. doi.org/10.1080/23312521.2014.898391

Braye, Stuart. 2017. “'You Shall Not Murder’: Atos at the Paralympic Games.” Journal of Disability \& Religion. 21(2), 215-229.

Braye, Stuart, Kevin Dixon and Tom Gibbons. 2017. "Disabled Athletes as Outsiders to English Sporting National Identity.” In Sport and English National Identity, edited by Tom Gibbons and Dominic Malcolm, 125-139. London, Routledge.

Braye, Stuart, Kevin Dixon and Tom Gibbons. 2015. "The 2012 Paralympics and Perceptions of Disability in the UK." In The Impact of the London 2012 Olympic \& Paralympic Games: Diminishing Contrasts, Increasing Varieties, edited by Kevin Dixon \& Tom Gibbons, 15-34. Hampshire: Palgrave Pivot.

Brock, Brian, and John Swinton. 2012. Disability in the Christian Tradition: A Reader. Grand Rapids, Michigan: Wm. B. Eerdermans.

Campbell, Jane, and Michael Oliver. 1996. Disability Politics: Understanding our Past, Changing our Future. London, UK: Routledge. 
Deal, Mark. 2003. “Disabled People’s Attitudes Toward Other Impairment Groups: A Hierarchy of Impairments.” Disability \& Society 18 (7): 897-910. doi.org/10.1080/0968759032000127317

Department of Health. 2016. “Abortion Statistics, England and Wales 2015.” Accessed 24 August 2016:

https://www.gov.uk/government/uploads/system/uploads/attachment_data/file/529344/ Abortion Statistics 2015 v3.pdf

Department of Health Northern Ireland. 2016. "Northern Ireland Termination of Pregnancy Statistics 2015/16.” Accessed 6 February 2017: https://www.healthni.gov.uk/sites/default/files/publications/health/hs-termination-of-pregnancy-stats-1516.pdf

Department of Culture, Media and Sport (DCMS). 2013. "Report 5: Post-Games Evaluation: Meta-Evaluation of the Impacts and Legacy of The London 2012 Olympic Games and Paralympic Games, Summary Report.” Accessed 20 October 2013: https://www.gov.uk/government/uploads/system/uploads/attachment_data/file/224181/ 1188-B_Meta_Evaluation.pdf

Eckstein, Herbert, B., Geoffrey Hatcher and Eliot Slater. “1973. New Horizons in Medical Ethics: Severely Malformed Children.” British Medical Journal May (2): 284-286. doi.org/10.1136/bmj.2.5861.284

Eiesland, N. L. 1994. The Disabled God: Toward a Liberatory Theology of Disability. Nashville, USA: Abingdon Press. 
French, Sally. 1994. "What is Disability?” In On Equal Terms: Working with Disabled People, edited by Sally French, 3-16. Oxford, UK: Butterworth-Heinemann Ltd.

Gibson, Owen. 2012. “Drop the Word 'Disabled' From Games Coverage, Demands Paralympics Committee President.” The Guardian, August 26. http://www.theguardian.com/sport/2012/aug/26/paralympics-philip-craven-disableddisability

Gillibrand, John. 2010. Disabled Church - Disabled Society: The Implications of Autism for Philosophy, Theology and Politics. Jessica Kingsley Publishers.

Goodley, Dan. 2004. "Who is Disabled? Exploring the Scope of the Social Model of Disability.” In Disabling Barriers, Enabling Environments $2^{\text {nd }}$ ed, edited by John Swain, Sally French, Colin Barnes and Carol Thomas, 118-123. London, UK: Sage.

Giubilini, Alberto and Francesca Minerva. 2013. "After-Birth Abortion: Why Should the Baby Live?" Journal of Medical Ethics 38 (5): 261-263. doi.org/10.1136/medethics2011-100411

Hanauske-Abel, Hartmut M. 1996. "Not a Slippery Slope or Sudden Subversion: German Medicine and National Socialism in 1933.” British Medical Journal 313 (7070): 14531463. doi:10.1136/bmj.313.7070.1453. 
Hauerwas, Stanley. 2004a. "Must a Patient be a Person to be a Patient? Or, My Uncle Charlie is Not Much of a Person But He is Still My Uncle Charlie." In Critical Reflections on Stanley Hauerwas' Theology Of Disability: Disabling Society, Enabling Theology, edited by John Swinton, 113-119. London, UK: Routledge.

Hauerwas, Stanley. 2004b. "Reflection on Dependency: A Response to Responses to My Essay on Disability." In Critical Reflections on Stanley Hauerwas' Theology of Disability: Disabling Society, Enabling Theology, edited by John Swinton, 191-197. London, UK: Routledge.

Hauerwas, Stanley. 1986. Suffering Presence: Theological Reflections on Medicine, the Mentally Handicapped and the Church. Notre Dame, Indiana: University of Notre Dame Press.

Howe, P, David. 2011. "Cyborg and Supercrip: The Paralympics Technology and the (Dis)empowerment of Disabled Athletes.” Sociology 45 (5): 868-882. doi:10.1177/0038038511413421

Howe, P. David. 2008. "The Cultural Politics of the Paralympic Movement: Through an Anthropological Lens.” London, UK: Routledge.

Howe, P. David and Carwyn Jones. 2006. "Classification of Disabled Athletes:

(Dis)empowering the Paralympic Practice Community." Sociology of Sport Journal 23 (1): 29-46. doi.org/10.1123/ssj.23.1.29 
Hylton, Kevin. 2013. “Introduction.” In Sport Development: Policy, Process and Practice ( $3^{\text {rd }}$ edition), edited by Kevin Hylton, 1-10 London: Routledge.

International Paralympic Committee. 2015. “Strategic Plan 2015-2018.” Accessed November 162016.

https://www.paralympic.org/sites/default/files/document/150619133600866_2015_06+ $\underline{\text { IPC }+ \text { Strategic }+ \text { Plan+2015-2018_Digital.pdf }}$

Koop, C. Everett. 1980. The Right to Live, The Right to Die. Wheaton, Illinois: Life Cycle Books.

Koop, C. Everett. 1984. "The Slide to Auschwitz.” Afterword in Abortion and the Conscience of the Nation, by Ronald Reagan, 41-73. New York: Thomas Nelson.

Laing, Jacqueline A. 2013. "Infanticide: A Reply to Giubilini and Minerva." Journal of Medical Ethics (39): 336-340. doi.org/10.1136/medethics-2012-100664.

“'Let These Children Die’ Doctor Says.” 1972. The Times, August 12, 2.

Manninen, Bertha A. 2013. "Yes, The Baby Should Live: A Pro-Choice Response to Giubilini and Minerva.” Journal of Medical Ethics (39): 330-335. doi.org/10.1136/medethics-2012-100656.

“Medical Briefing: MRC’s Spina Bifida Survey.” 1982. The Times, October 22, 11. 
Morris, Wayne. 2008. Theology Without Words: Theology in the Deaf Community (Explorations in Practical Pastoral and Empirical Theology). London, UK: Routledge.

Muggeridge, Malcolm. 1980. "The Humane Holocaust." The Human Life Review VI (1): 1322. http://www.humanlifereview.com/issue/winter-1980/.

National Health Service Scotland. 2016. “Termination of Pregnancy Statistics.” Accessed February 6 2017. https://www.isdscotland.org/Health-Topics/SexualHealth/Publications/2016-05-31/2016-05-31-Terminations-Report.pdf

ONS (Office for National Statistics) 2008. "Abortion Statistics, England and Wales." Accessed July 132016. http://webarchive.nationalarchives.gov.uk/20130107105354/http://www.dh.gov.uk/en/P ublicationsandstatistics/Publications/PublicationsStatistics/DH_099285.

Oliver, Michael. 1990. The Politics of Disablement. London, UK: Macmillan.

Oliver, Michael. 1996. Understanding Disability, From Theory to Practice. London, UK: Macmillan.

Peers, Danielle. 2009. “(Dis)empowering Paralympic Histories: Absent athletes and Disabling Discourses.” Disability \& Society 24 (5): 653-665. doi:10.1080/09687590903011113 
Peers, Danielle. 2012. "Interrogating Disability: The (De)composition of a Recovering Paralympian." Qualitative Research in Sport, Exercise and Health 4 (2):175-188. doi.org/10.1080/2159676X.2012.685101

Pritchard, Megan. 2005. “Can There be Such a Thing as a 'Wrongful Birth'?” Disability \& Society 20 (1): 81-93. doi.org/10.1080/0968759042000283656.

Ray, Joanna, Z. 2006. Practical Theology: In Search of a 'Disabled' God. Raleigh, North Carolina, United States: Lulu.

RCOG (Royal College of Obstetricians and Gynaecologists). 2008. "RCOG Opinion: The Abortion Act, 40 Years On.” Accessed April 12 2017, https://www.rcog.org.uk/en/news/campaigns-and-opinions/human-fertilisation-andembryology-bill/rcog-opinion-the-abortion-act-40-years-on/

Reagan, Ronald. 1984. Abortion and the conscience of the nation. New York: Thomas Nelson.

Rostand, Jean. 1970. Humanly Possible: A Biologist's Notes on the Future of Mankind. Translated by Lowell Bair 1973. Toronto: Doubleday Canada Ltd.

Saunders, Peter. 2007. “Innocent Blood.” Triple Helix. Christian Medical Fellowship. Accessed July 132016. http://www.cmf.org.uk/resources/publications/content/?context=article\&id=1986 
Saxton, Marsha. 2017. "Disability Rights and Selective Abortion." In The Disability Studies Reader ( $5^{\text {th }}$ edition), edited by Lennard J. Davis, 73-86. London, UK: Routledge.

Shakespeare, Tom. 2017. “The Social Model of Disability.” In The Disability Studies Reader ( $5^{\text {th }}$ edition), edited by Lennard J. Davis, 193-203. London, UK: Routledge.

Shakespeare, Tom and Nicholas Watson. 1997. "Defending the Social Model." Disability \& Society 12 (2): 293-300.

Sharp, Keith and Sarah Earle. 2002. "Feminism, Abortion and Disability: Irreconcilable Differences?” Disability \& Society 17 (2): 137-145. doi:10.1080/09687590120122297.

Silver, J. Russell. 2011. “Karl Gebhardt (1897-1948): A Lost Man.” Journal of the Royal College of Physicians Edinburgh 41: 366-371. https://www.rcpe.ac.uk/sites/default/files/silver_0.pdf

“Sometimes Better to Let a Baby Die, Doctors Say.” 1973. The Times, May 8, 3

Tännsjö, Torbjörn. 1998. “Is Our Admiration for Sports Heroes Fascistoid?” Journal of the Philosophy of Sport XXV, 23-34. doi.org/10.1080/00948705.1998.9714566.

Thomas, Nigel. 2003. "Sport and Disability." In Sport and Society: A Student Introduction, edited by Barrie Houlihan, 105-124. London, UK: Sage.

"Prosecutions For Hate Crimes Against Disabled People Surge by More Than 40 Per Cent In a Year.” 2016. The Telegraph, July 13. Accessed July 20, 2016: 
http://www.telegraph.co.uk/news/2016/07/13/prosecutions-for-hate-crimes-againstdisabled-people-surge-by-mo/

Watson, Nick, .J. and Andrew Parker. 2015. Sports, Religion and Disability. London, UK: Routledge.

Williams, Arthur. 2012. "Paralympics 2012: It Cannot be Something That is Every Four Years.” The Guardian [Online], September 9. Accessed December 2, 2012. http://www.guardian.co.uk/sport/blog/2012/sep/09/paralympics-2012-funding-athletes. 